\title{
Research on the Training Model of the Reserved Talent of Registered Accountants in the Cooperation Education of Production, Teaching, Research and Research of Independent Accounting College
}

\author{
Lei Han \\ School of Xingzhi school, Xi'an Institute of Finance and Economics University, Xi'an 710038, China. \\ hanlei209@126.com
}

Keywords: Accounting specialty; Certified public accountant; Talent training model.

\begin{abstract}
With the growing demand for certified public accountants in China, various schools are also actively exploring ways to train applied certified public accountants. At present, China's schools have made remarkable achievements in the training of CPA professional personnel, but problems still exist. The article discusses how to cultivate the CPA professional students into application-type senior management talents with engineering background.
\end{abstract}

\section{Introduction}

From the perspective of science and technology development and economic development practice in various countries, in the process of building independent innovation capabilities and improving the national innovation system, knowledge-sharing cooperation plays an important role in giving full play to the basic role of the market in the allocation of scientific and technological resources. Give full play to the main role of enterprises in technological innovation, give full play to the backbone and leading role of national scientific research institutions, give full play to the role of the university's foundation and vital force, and vigorously strengthen cooperation among national scientific research institutions, universities, and enterprises to further form scientific and technological innovations. As a whole, the cooperation between Chinese enterprises and universities based on knowledge sharing has been rapidly developed in all directions. The knowledge of many universities has been rapidly transformed, and the productivity and technological innovation efficiency of enterprises have been greatly improved [1].

From the practice of knowledge-sharing of agro-industry cooperation, in spite of the mufti-perspective and multi-access exploration and practice of knowledge cooperation between enterprises and universities in China in recent years, the performance of knowledge-sharing cooperation between industry and university has been greatly improved and improved. There is no real need to meet the global competition of the industry [2]. In particular, with the further development of China's industrial structure adjustment in recent years, new situations, new problems and new trends have emerged in the knowledge-sharing of industry-academia cooperation.

How to construct a scientific and perfect professional training model for certified public accountants is a subject worthy of in-depth study by our front-line educators [3]. The CPA professional personnel training model in institutions of higher learning should be structured in terms of professional settings, personnel training objectives and training specifications, teaching content and curriculum, teaching methods and teaching methods, teaching management, and teaching evaluation.

\section{Talent Training Goals and Training Specifications}

\subsection{Talent Training Target.}

As the cradle of the CPA reserve talents, the CPA profession should pay equal attention to the higher and professional personnel training. The training goal should be aimed at cultivating high-qualified certified public accountants auditing professionals who can adapt to the needs of the 
socialist market economy, develop in an all-round manner, with a solid and profound theoretical basis and high professional and technical capabilities and professional adaptability. The vocational goals of graduates are to be registered as certified public accountants in a certified public accountant firm, mainly to accountancy firms engaged in audit verification, accounting consulting, and taxation consulting [4].

\subsection{Talent Training Specifications.}

\section{(1) Quality Structure Requirements}

The qualifications that certified public accountants have should include two aspects: First, basic qualities, including professional ethics, physical and mental qualities, and cultural qualities. The second is the special quality, which mainly refers to the sensitivity, insight, comprehensive analysis and judgment, and communication and exchange ability of auditing matters. This is a special occupational requirement for the auditing work of the CPA.

\section{(2) Capability Structure Requirements}

The capabilities that certified public accountants should possess include the ability to acquire knowledge and apply knowledge. Access to knowledge includes self-learning capabilities, computer and information technology application capabilities; application knowledge capabilities include integrated application knowledge to solve problem-solving, practical and presentation skills.

\section{(3) Knowledge Structure Requirements}

Certified public accountants should possess knowledge including humanities, social sciences, instrumental knowledge, and professional knowledge. Humanities and social science knowledge includes knowledge of ideology, ethics, law, sociology, and psychology; instrumental knowledge includes knowledge of foreign languages, computer and information technology applications, and writing of economic applications; professional knowledge includes basic knowledge and majors of the disciplines. Directional knowledge, such as professional knowledge in economics, management, auditing, accounting, economic law, etc.

\section{Advantages of the Cooperation Model of Production, Teaching, and Research of Accounting Specialty in Independent Colleges and Universities}

The impact of universities on corporate innovation capabilities is mainly reflected in the following aspects: First, collect and sort out the ability to package knowledge. The initial state of knowledge is scattered and disorderly, and knowledge can only be spread through knowledge integration. Second, tacit knowledge is explicit. Implicit knowledge can only be used by most people after being explicit, and a considerable part of the research results of university scholars is the result of explicit knowledge of tacit knowledge. The explicit knowledge of tacit knowledge is also a very important innovation ability [5]. Third, provide enterprises with knowledge analysis services. The university's knowledge service center can serve as a spectator to conduct knowledge diagnosis for the enterprise, analyze the company's knowledge structure, discover the company's knowledge "short board", and help the group companies improve their knowledge structure. Finally, promote the speed of knowledge transfer. If knowledge is used by mankind as early as one day, it will be able to create value for mankind as early as possible. Therefore, the speed with which knowledge is transmitted in society will directly affect the value it creates for society [6].

The influence of the enterprise on the innovative ability of the university is shown as follows. First, it affects the teaching process of the university. In higher education, knowledge is linked to "learning". Textbooks are examples of knowledge. The process of knowledge dissemination is "learning" and "learning" is a one-way process. The result of the study is based on a certain standard. It is measured by "correct" and "wrong". Therefore, in this mechanism, knowledge is still known as "inherited knowledge" and truthful knowledge. It is still traditional static knowledge. Through the transfer of corporate innovation capabilities, the university teaching process will become a dynamic knowledge transfer. Second, help universities meet the challenge of knowledge integration. In the case where cross-cutting research has become an important source of motivation for knowledge innovation, the traditional discipline classification has led to barriers between disciplines, which has 
seriously affected the efficiency and effectiveness of school production knowledge and has increasingly become an obstacle to knowledge innovation. Therefore, learning from the enterprise's technological innovation ability will help the university to break the boundaries of disciplines, create an environment for mutual exchanges, and focus on integration. Finally, help spread the university's knowledge in society. The traditional role of the university is to cultivate talents. As a talent base, the university is more responsible for the dissemination of knowledge to the social elite.

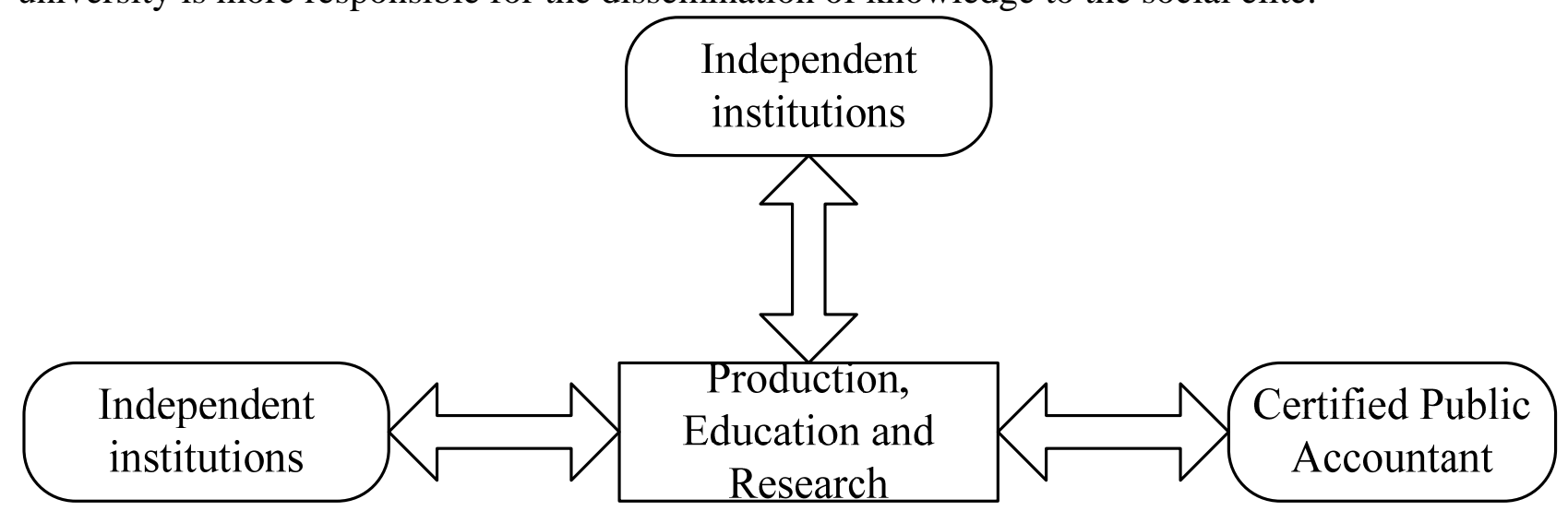

Fig 1. School CPA professional orientation talent training model

\section{School Certified Public Accountant Professional Orientation Talent Training Model Proposal}

\subsection{Course Design Suggestions.}

1) Accurately cultivate positioning and highlight the advantages of disciplines. The goal of training talents for CPA's in schools is mainly to adapt to the reserve talents working in the financial department and accounting firms of the company. On this basis, more accurate training orientations can be combined with the actual situation. For example, ore-service education can be strengthened and theoretical basic courses can be arranged closely. The balance can give more time to teach professional knowledge and help students better understand the professional orientation of CPA professionals. The role and significance in society and enable students to better lay a more valuable and solid foundation for future work. At the same time, it is necessary to highlight the discipline advantages of the CPA professional direction. After learning the basic knowledge of accounting, it is necessary to strengthen the deep learning of CPA professional courses, so that students can grasp the professional knowledge of the CPA professional direction earlier and better. Schools should do their utmost to highlight professors of certified public accountants' professional courses, highlight the focus of professional training of certified public accountants, and cultivate high-quality, professional talents who can quickly integrate into society.

2) Reform the teaching model and develop it from time to time. Schools should pay close attention to the relevant provisions of the "Guidelines for Competence of Chinese Certified Public Accountants", follow the footsteps of the Chinese Institute of Certified Public Accountants, and grasp the new requirements of the current era for CPA professionals. After mastering the general direction of reform, it has boldly reformed the traditional teaching model based on theoretical education, simplifies related operational procedures, and provides convenience for the reform of teaching models. At the same time, under the background of the development of the times, both theoretical education and vocational education should be given equal emphasis. This requires students to lay a good foundation for theory, but also requires that students master the professional skills necessary for the job and strive to achieve a smooth entry into the school. CPA industry related skills.

\subsection{Making Full Use of Teaching Resources.}

1) Strengthen school collaboration and cultivate diverse talents. The talents that cultivate the professional direction of CPA's in schools ultimately serve the industry, and enterprises are the carriers of the CPA industry. If the school wants to achieve better results in cultivating professional talents for CPA's, it is inseparable from in-depth cooperation with enterprises, understanding of 
business needs and training on an as-needed basis, and is committed to cultivating quality talents that companies lack and need urgently. Therefore, it is suggested that schools should strengthen school-enterprise cooperation and cultivate diversified talents that meet the needs of enterprises. There are many forms of strengthening school-enterprise cooperation, such as signing school-industry internship contracts, providing students with a platform for internships, providing more and better internship opportunities, and allowing more students to have good opportunities for internship; Schools and enterprises jointly develop research projects, schools use their own strong knowledge and skills, companies use their own practical experience and grasp of market conditions, the two sides cooperation and win-win, the greater the chance of success.

2) Hire an expert team to understand the industry. Schools can vigorously develop the practice of inviting large corporate chief accountants or partners of large accounting firms to serve as practical instructors for students. The school personnel is considered to be the top talent in the entire CPA industry and represents the demand body for the CPA industry's talent market. They are more valuable for the evaluation of students' professional abilities and qualities. Having these god-level characters instructing the students in the school can give them a higher level of understanding of what they have learned. At the same time, through the guidance of the CPA industry's talent demand subject, students will be more easily accepted by the industry talent market in the future. In addition, hiring a team of experts to guide the school can also infuse different vitality into the school and promote schools to cultivate professional talent in the direction of certified public accountants. At the same time, the expert team's guidance to students also reveals more substantive content and the latest industry information in the industry, which helps schools and students to understand the industry in depth.

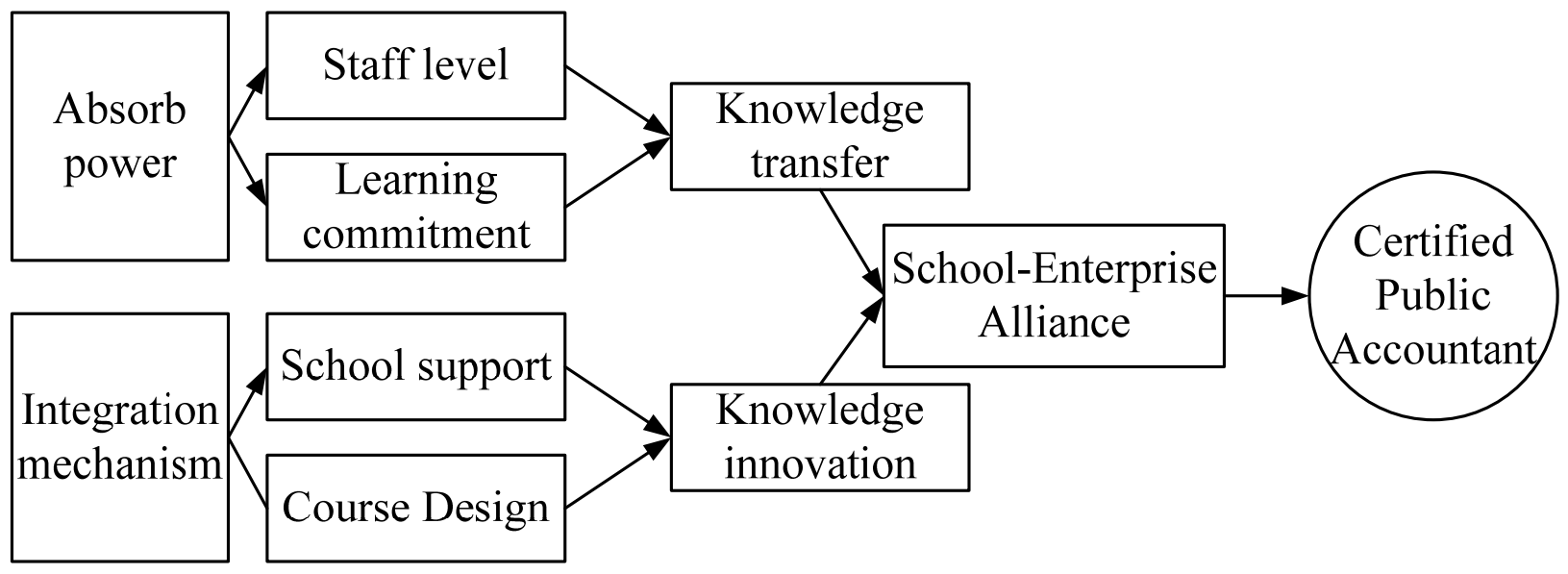

Fig 2. CPA Reserve Talents Training Model

\subsection{Intensify Practical Teaching, Focusing on Practical Effects.}

1) The school adjusted course modules to increase the proportion of practical teaching. In the transition from local schools to applied ones, strengthening practical teaching is an important part of teaching reform. When formulating the talent training program, we can increase the concentration of practical teaching modules, and set up purely practical courses such as professional integrated practical training, cross-professional integrated training, cognitive practice, and social surveys; and in the elective courses, we will set up school training and accounting posts. Training, financial decision-making training and other more practical courses for students to choose; in the basic accounting, intermediate financial accounting, auditing and other traditional theoretical courses can increase the practice of teaching hours, and ultimately make practice teaching credits accounted for $20 \%$ of the total credit - $30 \%$.

2) Build a mufti-dimensional practical teaching platform. The multi-skilling practice teaching platform refers to both on-campus training and off-campus practice. It integrates manual experiments, on-board experiments, all-reality simulation experiments, and off-campus practice bases in schools. The school realizes "hand-made experiments + hands-on experiments + real-life simulations. 
Multidimensional Practical Teaching Framework of "Experiment + Enterprise Practice". First, optimize the school's experimental platform. Traditional on-campus experiments mainly include manual accounting experiments and computerized accounting experiments. These experiments have the characteristics of single experimental materials and monotonous experimental methods. Students have little interest in learning and poor learning persistence. Schools should introduce more high-simulation simulation experiments, such as ERP sand table experiments, commercial warfare training, accounting sub-post training, etc., so that students can experience the business process flow of different departments in the enterprise immersible, and enhance the students' business management. Macro-cognition improves students' interest in learning. For the CPA profession, an integrated audit training course should also be set up, teaching version audit software should be introduced, simulation cases should be used, audit training should be carried out to improve students' practical ability to operate audit software, and secondly, a diversified off-campus practice base should be established. In the curriculum of the personnel training program, cognitive internships, social surveys, professional internships, and graduation internships are all off-campus internships. However, due to the fact that the school's off-campus practice base is relatively small, it is unable to provide students with enough internship opportunities, and the students themselves are very Difficult to find short-term internships, so many off-campus internships often flow in form. Schools should strengthen the development and construction of off-campus practice bases. In addition to cooperating with accounting firms, they can also cooperate with agencies such as bookkeeping companies and provide adequate support in terms of system and funding, in different periods and batches. The second guides students to conduct internships outside school. Schools can set up a rolling experiment week for each semester and arrange different students for different specialties and classes to conduct internships at different times so as to avoid internship times concentrated at the end of the semester or winter vacations, resulting in insufficient internships. At the same time, the supervision of the process of off-campus internships should be strengthened, and students should be required to provide photos, audio-visual materials, survey reports, and internship reports.

\section{Conclusion}

Industry-university cooperation knowledge sharing means that both companies and universities use information technology and various communication methods. Knowledge subjects consciously share information and knowledge with each other and realize bidirectional flow and learning of knowledge with different characteristics. And creation, thereby facilitating the process of knowledge growth and knowledge innovation at different levels of organization between the enterprise and the university. The definition of the concept of knowledge-sharing of industry-university cooperation has broken through the unidirectional nature of the original knowledge transfer and transformed it into a bidirectional flow of knowledge. It not only analyzes the enterprise, but also analyzes the situation of knowledge innovation after universities participate in the cooperation between industry and universities, especially the value of knowledge sharing between the two parties. The process of achieving, spiraling, cooperating multiple times, and jointly benefiting, the training of talents in independent colleges and universities is a problem for educators Chang Sichang. Training professional students of CPA s into application-oriented senior management talents with engineering background is our constant pursuit. Goals and responsibilities. In the specific teaching work, train students to master the theory and methods of finance, have good integrity and professional ethics, systematically grasp the basic financial theory and financial management methods under the modern company system and capital market environment, and have practical operations on the financial issues of the company. Ability to engage in corporate finance and capital management. 


\section{Acknowledgements}

This work was supported by the "Study on the Training Model of the CPA Reserve Talents in the Cooperation Education of Professional Colleges, Universities and Finance Institutes for Independent Institutes of Higher Education” (Project No. SGH17H396).

\section{References}

[1]. Yan Hua Yun, Hu Juan, et al. Research on the CPA Training Model in the Background of Collaborative Innovation. Friends of Accounting, Vol. 6 (2015) No. 23, p.125-129.

[2]. Sun Raja, Zhang Zhongyue, et al. Research on CPA training model from the perspective of CPA development. Shopping mall modernization, Vol. 9 (2016) No. 16, p.131-136.

[3]. Wang Jiangmen, Chen Chunking, et al. Intellectual Property and Knowledge Sharing Economic Forum, Vol. 8 (2013) No. 34, p.132-137.

[4]. Lin Huiyue, Li, ET al. Fang on knowledge sharing] natural dialectics research, Vol. 2 (2012) No. 29, p.216-221.

[5]. Sun Rui, Zhao Dali, et al. Evolutionary Game Analysis of Dynamic Alliance Knowledge Sharing, Operational Management, Vol. 10 (2009) No. 31, p.325-329.

[6]. Hu Yanking, Liu Xiamen, et al. Game Analysis of Knowledge Sharing in Knowledge Alliance Science and Technology Progress and Countermeasure, Vol. 6 (2015) No. 35, p.331-336. 